\section{Troubles never come singly}

\section{Washington}

Continuing problems in the US space programme this week prompted the White House to ask NASA (the US National Aeronautics and Space Administration) to set up a new task force of outside experts to consider the agency's long-term goals. The request came on Monday during a meeting between VicePresident Dan Quayle, chairman of the National Space Council, and NASA administrator Richard Truly. Earlier, it was rumoured that the council might force major changes upon NASA. But Quayle said a shake-up was not planned. The new task force will, however, report to Quayle and signals a continuation of his growing interest in controlling the space programme (see Nature 343, 310; 1990).

The past weeks have seen the discovery of flaws in the optics of the Hubble Space Telescope, the grounding of the shuttle fleet due to a mysterious fuel leak (see page 207), debate over a rash of apparent problems with the design of the Space Station, and congressional budgetary

\section{EUROPEAN SPACE AGENCY}

\section{Remote-sensing satellite agreement}

\section{London \& Paris}

AFTER almost a year of uncertainty, the goahead has been given to build a second European remote-sensing satellite (ERS-2). At a European Space Agency (ESA) council meeting at the end of last month, France finally decided to contribute 23 per cent of the satellite's $£ 297$ million costs, bringing the total commitment from member states so far to 80 per cent.

At ESA headquarters in Paris last week, no one was willing to give a precise breakdown of funding for the satellite, as some partners, notably Italy, have not yet specified exactly how much they are prepared to commit. It is, however, expected that they will foot about 13 per cent of the bill.

News of the go-ahead for ERS-2 was greeted with relief within ESA. Last autumn there were fears that rising costs of the Columbus programme, including the Hermes shuttle and Ariane 5 launcher, would jeopardize the satellite. And France has its own Spot remote-sensing satellite programme, although with very different capabilities and aims. But ERS-2 is seen as vital to provide continuity with ERS-1, set for launch next spring, and the polar observation platform planned for 1997, part of the Columbus programme. ERS-2 is expected to be about 50 per cent cheaper to build than ERS-1 and will share some basic components with the French Spot satellites.

Peter Coles \& Peter Aldous assaults on several of NASA's projects.

"NASA is down but not out. We'll bounce back", says William Lenoir, associate administrator for space flight at NASA. A roller coaster ride is nothing new for NASA; following the low of the Columbia Space Shuttle crash in 1986, NASA came back with last year's triumphant Voyager flyby of Neptune.

NASA's future problems will be compounded by this week's news that the budget deficit for fiscal year 1991 is likely to be $\$ 168,000$ million, rather than the $\$ 100,000$ million predicted by President George Bush in January. To avoid triggering across-the-board cuts under the Gramm-Rudman Act, the White House and Congress must find ways to reduce the deficit to $\$ 64,000$ million - a task that will require huge cuts.

Action in the House of Representatives has already cut the president's budget request for NASA by $\$ 800$ million to $\$ 14,300$ million. Out went funds for a programme to search for intelligent extraterrestrial life - "let space aliens use their currency to find us", was the comment of Silvio Conte (Republican, Massachusetts) during debate in the House. Out also went funding for Bush's plan to land humans on Mars sometime early next century. Bush protested vigorously when cuts were suggested at the committee stage, accusing Congress of abandoning the American "pioneering spirit".

The House has also taken a tough stand on plans for the Space Station Freedom, taking the unusual step of writing a proviso into its appropriations bill that would cut off funding if power supply problems are not overcome by the year-end preliminary design review. The station is limited in the total power available to the $75 \mathrm{~kW}$ supplied by its array of solar panels. But so much of that power is needed for housekeeping functions that NASA can guarantee only $15 \mathrm{~kW}$ - a third of that originally planned - for scientists using the station.

Last week, Richard Kohrs, director of Space Station Freedom, said that the problem was not as bad as it seemed. Estimates of power demand had included excessive use of equipment such as microwave ovens. But other big savings still need to be found. Kohrs says that NASA is now examining ways of reducing the number of measurements of such things as temperature, pressure and air flow to reduce power demand.

Two other big problems with the space station worry Congress. By far the most intractable is that the station is now too heavy. The scale of the weight problems was revealed last week in a NASA report leaked to Space Station News, a Washington-based newsletter. The space station is 150,000 pounds over its total weight target of 500,000 pounds.

Simply adding shuttle flights to build a heavier station would not win NASA points for strict management. Last week, Kohrs said that weight problems would be overcome and were not unusual at this stage of the design process. He presented graphs showing that the design weight of the station was now falling. If cuts can be continued at the same pace, the station will slim to the right weight just in time for the preliminary design review.

A new problem comes from NASA's most recent calculations of the time that astronauts will have to spend outside the station carrying out routine repairs. At first, only a couple of hundred hours of 'space walks' was thought likely to be necessary each year. A NASA report in February this year pushed the number up to over 2,000 hours. Now the figure is rising again. Space walks are considered dangerous and the effect of long exposure to space radiation is unknown.

Trouble is also looming for another of NASA's giant projects in a National Academy of Science's report, due out in mid-August, that will continue the debate over whether NASA should launch giant satellites as part of its Mission to Planet Earth (see Nature 344, 578; 12 April 1990). The mission, intended to understand global environmental changes, will include massive Earth Observing System (EOS) platforms, each carrying an elaborate suite of instruments. As confidence slips in NASA's ability to successfully manage large projects, the question is whether the platforms should be replaced by simpler satellites.

In principle, large satellites make more sense. They are cheaper to operate and can make the many simultaneous measurements, looking through the same air path, that are essential to model accurately the global environment. But the same data could be provided at less risk of a catastrophic failure by using a train of small satellites, following one another closely. Small satellites are also more flexible as frequent launches provide opportunities to add the most advanced sensor technology or to change instruments as new questions emerge.

More important, as pointed out in a briefing published last week by the American Institute of Aeronautics and Astronautics, clouds "cannot be studied effectively" by the EOS platforms. Yet long-term changes in cloud cover remain one of the key unknowns in predicting global warming.

NASA says that difficulties in large programmes have often arisen as a result of work being divided among several centres. Work on the Hubble Space Telescope was divided between two centres, that on the space station among four. EOS will be run entirely from Goddard Space Flight Center. 